\title{
Hedonic Price Modeling of the Influence of Violent Ethno-Religious Conflict on Residential Property Values in Bauchi Metropolis, Nigeria
}

\author{
Yusuf L. Gambo ${ }^{1}$ \\ ${ }^{1}$ Department of Estate Management, Abubakar Tafawa Balewa University, Bauchi, Nigeria \\ Correspondence: Yusuf L. Gambo, Department of Estate Management, Abubakar Tafawa Balewa University, \\ Bauchi, Nigeria. Tel: 234-806-508-8652. E-mail: yusuf_gambo@yahoo.com
}

Received: May 28, 2012 Accepted: July 11, 2012 Online Published: August 24, 2012

doi:10.5539/jsd.v5n9p85 URL: http://dx.doi.org/10.5539/jsd.v5n9p85

\begin{abstract}
The study examines the influence of violent ethno religious conflict on residential property values in Bauchi, Nigeria. The hedonic price model was used to capture the variable determining residential property values in the study area. Following collinearity observed among the initial 40 variables observed, a careful backward elimination process was used to whittle the variables to 13 . The results show that conflict free area is the most influential variable determining rent. The study recommends among others, that Estate Surveyors and Valuers need to give cognizance and incorporate market response to social disorder in their valuation and also strategize and analyse in more depth, before advising clients on real property investment.
\end{abstract}

Keywords: Ethno-religious conflict, residential property value, hedonic, Northern Nigeria

\section{Introduction}

Recently Nigeria has been rattled by recurrent religious and ethno-religious conflicts especially from the late eighties, precisely, 1987. The specters of violence occasioned by inter and intra religious, ethno-religious or inter-ethnic conflict has become a retrogressive social enterprise in Africa. In Nigeria, especially in Northern part of the country, ethno religious fracas has assumed a dreadful dimension. The level of notoriety it has acquired does not only affect the peace and pattern of development, it has started to take its tolls on property investment and values, particularly in the northern states of Bauchi, Plateau, Kaduna, Kano.

Conflict can be an inherent and legitimate part of social and political life, but in many places the costs and adverse consequences of conflict have become unacceptably high. Conflict is an important issue in many ethnically diverse countries and its spread has dramatically disrupts traditional development and can spill over borders and reduce growth and prosperity across entire regions (Horowitz, 1985; US Agency for International Development, 2009). Conflict is often viewed as negative and dysfunctional, abnormal and detestable. However, Kukah (2000) sees conflict as constructive social action, an agent for reclassification of society, which has helped to catalyze social decay into positive social progress and development.

Violent mutiny destroys infrastructure, services, assets and livelihoods, displaces populations, breaks social cohesion, institutions and norms and also creates fear and distrust. Ethno religious conflicts have swept many lives and properties worth billions of naira. The large scale destruction of houses, places of worship and shops forced a large number of people in the affected area to be displaced. Many opted to relocate outside their normal places of abode or even outside the state for their safety. This in turn affected the demand for real properties particularly residential properties.

Residential property values are influenced by external and internal factors. The former has to do with the state of the economy, demography, location, transportation, and neighbourhood characteristics; while the latter is concerned with the property specifics such as, age, size, design, and accommodation details. Various studies on house price that employed hedonic model have categorized these factors into locational, structural and neighbourhood attributes (Gallimore et al., 1994; Ebru \& ban, 2011). Locational attributes that have been widely considered include distance to Central Business Districts (McMillien, 1990), transportation cost (So et al., 1996), impact of cemetery view on house price (Tse \& Love, 2000). Studies that centred on structural attributes capture age, number of rooms, design, cooling system, etc (Ball, 1973; Kohlhase, 1991). While neighbourhood attributes include noise, air pollution, crime (Nelson, 1978; Lin \& Brown, 1980; Buck et al., 1991). Most of these studies 
were towards housing market in the West America and Europe in particular. Recently, there are studies in Asia utilising hedonic technique to examine preferences in residential attributes and measuring house prices. Prominently among these include Mok et al. (1995), So et al. (1996), Tse and Love (2000), Chau et al. (2001), Choy et al. (2007) in Hong Kong, Edmond (1984) in Japan; Hsueh (2000) in Taiwan; Mishra and Ngullie (2008) in India. Olayiwola et al. (2005) remarked that many of the studies relating to urban land system carried out in many parts of the world were done under social, cultural, economic and political situations different from the Nigerian situation and therefore cannot reflect its peculiarity.

As at today, empirical studies on hedonic price model in Nigeria are scanty besides the works of Megbolugbe (1989); Afolayan (2006); Bello and Bello (2007); Bello and Bello (2008); Ajide and Alabi (2010); Otegbulu and Johnson (2011); Babawale and Adewunmi (2011); Babawale and Johnson (2012); and Otegbulu et al. (2012). However, the studies were on Lagos metropolis and South-West except study by Megbolugbe (1989). More importantly, none of these studies capture the response of residential market to social disorder. This study will examine the influence of ethno religious conflict on residential property values in Northern Nigeria. The Study is segmented into sections. Section one provides the introductory background, section two reviews related literature, followed by the next section which presents the research methodology. Section four discusses the results while the last section gives the study implication and concluding remarks.

\section{Literature Review}

\subsection{Trends of Ethno Religious Conflicts in Northern Nigeria}

Most of the violent conflicts in Northern Nigerian have been either purely religious or ethno-religious (Bako, 1994; Mohammed, 2004; Institute for Peace and Conflict Resolution, 2003; Bogoro, 2008; FAcE PaM, 2008). The recent increase in violence in intra- religious conflicts is a worrisome development that has caught the attention of international communities. In some cases, ethnicity has added a new dimension to religious conflicts in Northern Nigeria (Bogoro, 2008). The tendency to identify some ethnic groups with a particular religion easily gives credence to the use of religion for the manipulation of other differences.

The expansion of Sharia legal system by some state governments further heightened the tension between Muslims and Christians. The situation is made worse with the presence of armed religious groups and the Hisbah (local religious security) to monitor the implementation of the sharia legal system at local level. The activities and proliferation of the new generation Christian churches in terms of aggressive preaching and indiscriminate constructions of churches in residential areas that are dominated by Muslims also have the potential of generating conflict in some states of Northern Nigeria that are predominantly Muslims. Bako (1994) viewed inter religious conflict as consisting of different ethnic groups belonging to Islam and Christianity, battling along majority/minority and indigene/settler divides within a frame work of ethno religious domination and struggle for liberation. This form of religious conflict he added, exist between minority Hausa- Fulani Muslim groups resident in predominantly non Hausa Christian areas, in the northern towns and cities. Example of such conflicts are those between the Hausa and Southern Kaduna ethnic groups from Kafanchan; the Hausa and the Kataf; the Hausa and the Sayawa; the Hausa and the Jukun; the Hausa and the Birom etc over the ownership of towns, sharing of religious space, land, market, fishing ponds, rulership, chieftaincies and participation in local government election.

The intra religious tension, especially among Muslims is another palpable generator of conflict. In the opinion of Bako (1994), in northern Nigeria, Muslim intra sectarianism has manifested itself in the large scale maitatsine insurrections which took place in the northern cities of Kano, Maiduguri, Kaduna, Gombe, Yola and Funtua between 1980 and 1993. Recently the Boko haram, an Islamic sect known for its hatred and rejection of western education had raided the cities of Maiduguri and Bauchi agitating for implementation of Islamic law in Northern States of the country. While there were no references to Christian intra religious conflict by the (IPCR, 2003). Bako (1994) further remarked that a Christian movement similar to the Maitatsine can be identified in the 'militant,' born 'again' movement among the urban poor and proletarian groups opposed to the dominant, orthodox Christian movements, though he concluded that their operation is less organized and violent than the Maitatsine.

Another factor that sparks up ethno religious violent conflicts is indigene/settler divides. In many parts of Nigeria, the issue of indigeneity seems to create new kind of tension where none had existed before. According to HRW (2006), the issue of indigene/settler divides began to take on increase importance not long after Nigeria's independence with regional policies that discriminated against the indigenes in having access to land (Brennan, 2005). The indigene-settler question in urban areas in Nigeria has produced violent conflicts in varying degree as witnessed in Kasuwan Magani (1980), Zango Kataf and Gure Kahagu (1984), Kafanchan et al. 
(1987), Ilorin and Jere (1987), Tafawa Balewa and Bauchi (1991), Zango Kataf (1992), Tiv and Idoma (1993), (Bako 1994; Dung, 1994). These conflicts often start as local conflicts but later spread to other areas (Dung, 1994). Religious factors have also played a crucial role in the generation and expansion of these conflicts, especially in situations where the religious and political boundaries overlap.

The Indigene/settler fracas most often than not culminate into ethno-religious violent conflicts in the north. Example include: the Maitatsine insurrections which took place in the northern cities of Kano, Maiduguri, Kaduna, Gombe, Yola and Funtua between 1980 and 1993; Kano riot (1984); Tungdo-Wudugu (1989); Hausa/Fulani and Sayawa in Tafawa Balewa in Bauchi State (1991, 1995, 2001, 2005 and 2011); Bauchi religious crisis (1991, 2006, \&2007); Hausa and Kataf (1992); Hausa and Berom in Jos (1994); Kaduna sharia conflict (2000); Jos/Plateau State (2001, 2002, 2008, 2010, 2011); Bako (1994); IPCR (2003); Bogoro (2008); FAcE-PaM (2008); Gambo (2009).

\subsection{Neighbourhoods Security, Crime, and Property Value}

Property values are influenced by environmental factors and property specific attributes. These attributes according to Bello and Bello (2007) can be classified into external and internal. External variables include the state of the economy, population, employment, immigration, finance, location, transportation, and neighbourhood amenities; while the internal factors comprise of the size, accommodation details, condition, design, layout, age, etc.

Crime is an environmental menace that affects urban livability globally (Monk, 1993; Danbazau, 1994 cited in Nyabvedzi \& Chirisa, 2012). A popular view shared by criminologists is that crime is dynamic, new forms of crime emerges and old firms assume new dimensions. Nyabvedzi and Chirisa (2012) assert that residents of a neighborhood are very sensitive to safety issues and occurrence of violence and crime in a particular place affect travel pattern and in extreme cases, property values are affected. Residents prone to crime and violent conflicts have an increase probability of moving (Dugan, 1999), and households that have already decided to relocate will consider safety issues in choosing new locations (Frey, 1979).

Crime is a local issue and its manifestation affect residential formation in a particular neighborhood. Understanding the relationship between property values and crime risk is important in determining the willingness of residents to live in the neighborhood and how much to pay to remain safe. Neighborhoods with high profile crime experience decrease demand from home buyers which subsequently affect the prices residential property in the neighborhood (Flippen, 2004).

Empirical survey points to a relationship between crime and property values, while available literature establishing the relationship includes (Gibbons, 2004; Social Exclusion Unit, 2001; Lynch \& Rasmussen, 2001; Haurin \& Brasington, 1996; Buck et al. (1991); Buck \& Hakim, 1989; Manning, 1986; Dubin \& Goodman, 1982; Thaler, 1978). Not all the research is in agreement.

There are evidences that crime and violence context affects individual choice of residential space (Moreneff \& Sampson, 1997). Moreneff \& Sampson (1997) assert that increase crime can have negative consequences for neighbourhoods, including increase relocation.

Manning (1986) found that crime had no significant impact on the property value appreciation while in the same vein Lynch and Rasmussen (2001) indicated little impact on housing sale prices. However, Thaler (1978) in an earlier study found a relationship between property crimes per capital and property values. His analysis show a one standard deviation increase in the incidence of property crime reduces residential property values by about 3 percent. Social Exclusion Unit (2001) remarked that residential property consumers or investors would always be concerned with the crime rate in the neighborhood before concluding their choice, hence in a high crime-prone areas, rental or slakes value tend to decline.

Gibbson (2004) in a recent study assert that no matter the nature of crime, it will have dynamic effect informed by household location decision which in turn affects the price of properties. He funds a decrease in property values of 10 per cent for a one-standard deviation increase in property crime and unemployment rates acquire poor reputations as a result properties in the area are labeled with bad attributes and subsequently attracts low values.

Security or lack of it is increasingly identified as a key problem in the urban neighborhood. Insecurity has disrupted organized settlement and exacerbated residential mobility. The importance of ensuring neighborhood security has been identified by leading politicians, academics and senior figures across the public services (Innes \& Jones, 2006). 
Rogers (2005) argued that growing concern over insecurity is the fundamental reasons that made English middle class reject urban living. Innes \& Jones (2006) remarked that crime disorder, antisocial behavior and fear of crime have an important role in shaping different localities and the perception of people that inhibit them. Disorder and crime make people fearful, destroy social networks and urban neighborhood less attractive to live in. Although there is a complex relationship in trying to identify how crime, disorder and fear might be either a cause or consequence of wider change process. Wilson and kellings (1982) "broken windows thesis" attempted to clarify the nexus. Wilson and Kellings (1982) arranged crime, disorder and fear of crime in a particular causal sequence. It stresses the importance of formal and informal social control, and how the nature of such responses can make a neighborhood worse and in conducive for long over time. The broken window thesis has major contribution in explaining the relationship between disorder, crime and fear of crime as it affects a society.

\subsection{Hedonic Price Model}

Hedonic price model is based on the recognition and treatment of the complexity and heterogeneity of the housing product. The model focus on markets in which a commodity can be embedded with varying amount of each of a vector of utility-bearing attributes (Rosen, 1974). The model was first performed by Court (1939) followed by Griliches $(1961,1971)$ who utilized the technique for the automobile industry. However, the housing market is the most prominent in the use of the technique. Lorenz (2006) observed that the technique has been employed to achieve three main goals in the housing market- to explain the price formation of residential property assets by identifying the main determinants of property prices; to isolate and quantify the impact of different physical, locational, and neighbourhood characteristics on property prices; and to account for changes in the price formation process across region or even time. The basic structure of a hedonic model takes the market price as the dependent variable and take all the attributes of the product (house in this case) as independent variables. For the housing market, the independent variables are classified into Locational, structural and neighbourhood attributes. The location attributes relates to accessibility to CBD, recreational facilities, place of worship etc. The structural characteristics refers to the physical attributes of the property such as number of rooms, age of the building, room size, plot size etc. While the neighbourhood characteristics, covers the socio-economic characteristics of the people living in the neighbourhood such as social status, racial composition etc. This study considers religious affinity, tribal affinity and conflict free areas as attributes of neighbourhood characteristics.

Few of the studies that utilize hedonic price model in Nigeria include Megbolugbe (1989); Afolayan (2006); Bello and Bello (2007), Ajide and Alabi (2010); Otegbulu, Johnson and Odekoya (2011); and Babawale and Adewunmi (2011).

Megbolugbe (1989) presents empirical evidence that describe Jos housing market in Nigeria. The frailty of the study is the use of property rating value as a proxy for market value. Rating valuation is a statutory valuation and does not reflect true market transaction and therefore subject to the inconsistencies inherent in the non-market valuations.

Afolayan (2006) was on the impact of the lagoon water on value of residential properties in Victoria Garden City (VGC) in Lagos. The study used 107 samples of housing units which is rather small to generalize and failed to clarify and justify how property values were estimated in the absence of data bank for property sales.

Bello and Bello (2007) examine the influence of consumer behaviour on the values of residential properties in Lagos metropolis, from both the perspectives of the valuers and the buyers. The results showed location as the most significant factor for duplexes and for flats, while perceived neighbourhood security was the most significant factor from buyers' perspective and location was considered by valuers. This study by Bello and Bello failed to make a distinction between low, medium and high-income sub-markets for flats and duplexes within the metropolis. They generalised their findings which may leave out vital information that could be of importance for policy decision.

Ajide and Alabi (2010) examine which of the three standard functional forms of the hedonic model (linear, semi-log and double $\log$ ) is the most efficient. The study adjudged the semi-log as the efficient having the highest coefficient of determination.

Otegbulu, Johnson and Odekoya (2011) examine the influence of physical and locational attributes, services provided and occupancy restrictions on service apartments in Ikoyi, Lagos. The study employed semi-log functional form to evaluate the attributes that determine the rent of service apartment. The results show that miscellaneous amenities, utilities, en-suet rooms, 24 hour electricity, number of bedrooms, modern kitchen, balcony, full air conditioning, quality of furnishing, are the most important attributes influencing the rent of serviced apartments. 
Babawale and Adewunmi (2011) investigate the impact of neighbourhood churches on residential property values with some selected areas of Lagos metropolis. The study employed the semi-log functional form. The study reveals that religious properties constitute negative externalities, however a positive externalities exist in close proximity. Their study concur with Do, Wilbur and Short (1994) study in San Diego whose findings reveal a significant impact of neighbourhood church on surrounding housing values and such impact decreases with increase in distance from the church. Tse and Kive (2000) found that a cemetery view has a negative impact on a property's price in Hong Kong. Generally, dwellings that have a cemetery are avoided. This is because view of a cemetery is regarded by the Chinese as inauspicious as it connotes death and is definitely bad. All these studies demonstrate how the hedonic price model captures the various housing attributes in the housing market.

\section{Model Specification}

Tse and Love (2000) noted that the housing prices are measured by the demand for their attributes from the region in which the market are located. This implies each market or sub-market produce its own set of hedonic prices. A traditional hedonic price model as specify by Rosen (1974), is used to examine the effect of Locational, structural and neighbourhood attributes determining house prices. In this study, the annual rnt of residential apartment are a function of many attributes and is expresses in the form:

$$
\mathrm{RTVL}=\mathrm{F}\{\mathrm{L}, \mathrm{S}, \mathrm{N}\}
$$

Where:

$\mathrm{RTVL}=$ Rental value of a property

$\mathrm{L}=$ Location attributes

$\mathrm{S}=$ Structural attributes

$\mathrm{N}=$ Neighbourhood attributes

There is no strong prediction of the correct choice of functional form. However, the choice of functional form that most appropriately explains the relationships between the explanatory variables and the property price is critical in expressing the variables involved in the model. More so, the problem of heteroskedasticity can be checked by choosing the most appropriate functional form. Three basic hedonic models are: linear, semi-log, and double log. This study adopts the linear function given consideration to the model with best $\mathrm{R}^{2}$, lowest Akaike info and Schwarz criteria, Durbin-Watson statistic and apriori expectation. The linear function is in the form:

$$
\mathrm{PTVL}=\alpha_{0}+\alpha_{\mathrm{i}} \mathrm{Z}_{\mathrm{i}}+€
$$

Where:

$\mathrm{RTVL}=$ Rental value of a property (Net)

$\alpha_{0}=$ Constant term

$\alpha_{\mathrm{i}} \mathrm{z}_{\mathrm{i}}=$ Variable characteristics

$€=$ Stochastic term

The set of housing variables considered relevant to the study are:

RELIGION $=1$ if the area is dominated by a particular religion (Christians or Muslims), otherwise 0

LOCATION $=1$ if you consider prestigious location against security, otherwise 0

CONFLICT $=1$ if the area is conflict free, otherwise 0

AGEBLD $=$ Age of building measured in years

DSTCTYWAL $=$ Distance to city wall in Kilometers (approx.)

DSTPLACEWRK = Distance to place of work in Kilometers (approx.)

DSTCHLDSCH = Distance to children school in Kilometers (approx.)

DSTPLAWOSHP = Distance to place of worship in Kilometers (approx.)

DSTMILTBARCK = Distance to military barracks (approx.)

DSTUNIPOLY = Distance to university/polytechnic (approx.)

DSTPUBHSPTL $=$ Distance to public hospital (approx.)

LIVAMGTRIB $=1$ if living among tribal group, otherwise 0

LIVAMGREL $=1$ if living among the same religious group, otherwise 0 
There is a general belief in the study area that living close to security outfits such as military barracks, police barracks and institutional areas (university and polytechnic) guaranty safety. Therefore people prefer to stay in close proximity to military barrack despite its distance away from the heart of the town (CBD). People stay among ethnic affiliation and religious affiliation for perceived safety. The city wall is the central business district (CBD) and is violent prone.

\section{Research Method}

\subsection{The Study Area}

The study area covers only Bauchi Metropolis, the capital of Bauchi State in Northern Nigeria where violent ethno religious conflicts are preponderant. The reason for selecting Bauchi state has recorded a series of violent ethno-religious fracas in recent time. Some of these ethno-religious crises include Hausa/Fulani and Sayawa crisis of Tafawa Balewa in 1991, 1995 and 2001; Ningi in 1991 and 2008; Bauchi crises in 1991, 2006, and 2007 in Yelwa all in Bauchi State (Bogoro, 2008; Gambo, 2009). Therefore, the impact of violent ethno-religious conflict can be easily captured within the scope of the study area.

This study employed regression analysis to examine the impact of violent ethno religious conflict along with other important variables that are known to influence house priced in the study area. Data were collected using structured questionnaire. The independent variables originally consisted of 40 independent variables but following collinearity observed among some variables, a backward elimination method was used to whittle the variables to 13 . Correlation technique was used to eliminate problem of collinearity by eliminating variables that were strongly correlated. To detect possible heteroskedasticity, the White's test was used. Both Akaike and Schwarz info criteria are very low in their values while Durbin-Watson statistic of 1.68, depicts absence of serial autocorrelation.

\section{Findings and Discussion}

Table 1 shows that conflict free area, age of the building, distance to military barracks, living among tribe, distance to university/polytechnic and distance to place of work, are significant at p-value $<0.1$. The first four in order of significance which are Conflict free area, Age of building, Distance to military barracks, Living among tribal group, were significant at $1 \%$ level; while the last two, Distance to university/polytechnic and Distance to place of work at $5 \%$ and $10 \%$ respectively.

Conflict free area with highest beta coefficient among other variables, contributes about $12 \%$ increase in rental value in conflict free zones. This implies that conflict is a major determinant of residential property rental value in the area. People desire to pay more in conflict free zones. Consideration of prestigious location does not really count to the people as against safety. Location has a prior negative beta coefficient. Age of building shows a negative impact on rental value. This implies the older the building the less the rent paid on such property. This is true as older a property getting, tears wears set in and the less value it commands; this is probably because of change in taste and design for aesthetics. This is however contradicting to the findings of Babawale and Adewunmi' (2011) that age of a building does not significantly affect rental values as capital value. Distance to military barrack has a positive beta coefficient with a corresponding increase in rent of above $11 \%$ away from the military barracks. This is however against the expected perceived believe that the closer a residential property is to the barracks the more the safety and the higher the rental property value. This finding negates positive contribution that staying close to military base adds to value, as living among tribal people, which is found in this study to add about $7 \%$ to value paid on accommodation unit. This is true in the study area, as demonstrated empirically that people choose to stay in close proximity to tribal people as this is tied to religion and religion is factored into safety. Comparably, distance from place of work has no significant influence on rent which means, tribal affinity is more important than nearness to place of work. Distance from university/or polytechnics is found contributing in a negative value rather than in a positive one. This implies that institutional settings influence rent paid on residential property in close proximity. It is believe that living in close proximity to university/polytechnic is safe because ethno religious conflict does not spread to such areas.

In Table 2 the White Heteroskedasticity Test conducted yielded probability level, $\mathrm{p}$, with $1 \%$. This opposes the null hypothesis of presence of heteroskedasticity in the model which in means the error term is constant, conforming to the Ordinary Least Square (OLS) assumption. To establish the significance of the multiple causal-effect of the independent variable, F-statistic is significant at $1 \%(\mathrm{p}<0.0001)$ with 22.188 . This test would imply the accuracy of the examined factors in explaining changes in the rent paid on a particular accommodation. 
Table1. Results of the regression analysis

\begin{tabular}{lllll}
\hline Variable & $B$-Coefficient & Std. Error & t-Statistic & Prob. \\
\hline RELIGION & 0.070011 & 0.412119 & 0.169881 & 0.8658 \\
LOCATION & -0.312131 & 0.780818 & -0.399748 & 0.6910 \\
CONFLICT & 1.231204 & 0.441805 & 2.786755 & 0.0074 \\
AGEBLD & -0.517383 & 0.091462 & -5.656786 & 0.0000 \\
DSTCITWAL & 0.115129 & 0.449517 & 0.256117 & 0.79 \\
DSTPLACEWRK & -0.443529 & 0.237446 & -1.867918 & 0.0674 \\
DSTCHLDSCH & -0.092289 & 0.329123 & -0.280409 & 0.7803 \\
DSTPLAWRSHP & 0.028480 & 0.175743 & 0.162053 & 0.8719 \\
DSTMILTBARCK & 1.183631 & 0.318534 & 3.715864 & 0.0005 \\
DSTUNIVPOLY & 0.609184 & 0.243196 & 2.504904 & 0.0154 \\
DSTPUBHSPTL & -0.188603 & 0.474254 & -0.397683 & 0.6925 \\
LIVAMGTRIB & -0.694743 & 0.178999 & -3.881274 & 0.0003 \\
LIVAMGREL & 0.064491 & 1.156117 & 0.055783 & 0.9557 \\
C & 1.998287 & 2.783524 & 0.717898 & 0.4760 \\
R $^{2}$ & 0.847258 & Mean dependent var & 3.030303 \\
Adjusted R & & S.D. dependent var & 1.239971 \\
S.E. of regression & 0.809073 & Akaike info criterion & 1.798023 \\
Sum Squared Resid & 0.541808 & Schwarz criterion & 2.262495 \\
Log likelihood & 15.26493 & F-statistic & 22.18797 \\
Durbin-Watson & -45.33475 & Prob(F-statistic) & 0.000000 \\
\hline & 1.676027 & &
\end{tabular}

Table 2. White heteroskedasticity test

\begin{tabular}{llll}
\hline F-statistic & 98.70822 & Probability & 0.000000 \\
Obs*R-squared & 64.41995 & Probability & 0.000001 \\
\hline
\end{tabular}

The beta coefficients of distance to children's school, distance to city wall and distance to public hospital are all desirable but insignificant enough to explain change in rental value. The city wall is the Central Business District (CBD) but has no influence on residential rental values because of its proneness to violent conflict. People in the area choose to stay away from the CBD to pay more rent. This is also implies that residential property away from the heart of the town command higher value against land rent theory of Von Thunen.

\section{Conclusion and Recommendations}

This study examines the impact of ethno religious conflict on residential property values in Northern Nigeria. The findings show that residential property values are majorly influenced by consideration of conflict free area and conflict prone neighbourhood.

This study is beneficial to property investors and consumers of residential property as it provides Practical information regarding where to invest and where not to, and where to live and/or where not to. Estate Surveyors and Valuers therefore need to strategize to analyse in more depth, the market responses to social disorders before advising clients on real property investment. There should be sincerity on the part of government in dealing with ethno-religious conflict and reports of committees set up to enquire into such violent conflicts; while religious and community leaders should re-educate their followers and subjects on the merit of peace and tolerance. 


\section{References}

Adebayo, M. A. (2006). The State of Urban Infrastructure and its Effects on Property Values in Lagos, Nigeria. Journal of Land Use and Development Studies, 2(1).

Afolayan, A. S. (2006). Environmental Externality and Housing Values: A study of Victoria Garden City, Lagos. Journal of Land use and Development Studies, 2, 79-90.

Ajide, K. B., \& Alabi, M. (2011). Does the Functional Form Matter in the Estimate of Hedonic Price Model for Housing Market? The Social Science, 5(6), 559-564.

Babawale, G. K., \& adewunmi, Y. (2011). The Impact of Neighbourhood Churches on House Prices. Journal of Sustainable development, 4(1).

Babawale, G. K., \& Johnson, O. (2012). The Specification of Hedonic Indexes for Duplex in Lekki Peninsular Area of Lagos Metropolis. Elixir Social Science, 45, 7689-7698.

Bako, S. (1994). Urbanization and Religious Conflicts in Nigeria. Proceeding of International Symposium on Urban Management and Urban Violence in Africa, Ibadan $7^{\text {th }}-11^{\text {th }}$ Nov.

Ball, M. (1973). Recent Empirical Work on the determinants of relative housing prices. Urban studies, 10, 213-233. http://dx.doi.org/10.1080/00420987320080311

Bello, M. O., \& Bello, V. A. (2007). The influence of Consumers Behaviours On the Variables Determining Residential property values in Lagos, Nigeria. American Journal of Applied Sciences, 4(10), 774-778. http://dx.doi.org/10.3844/ajassp.2007.774.778

Blunkett, D. (2004). Confident Communities in a Secure Britain. Home Office Press Release (237/2004).

Boggess, L. N., \& Hipp, J. (2010). Violent Crime, Residential Instability and Mobility: Does the Relationship Differ in Minority Neighbourhood? Journal Quant Criminol, 26, 351-370. http://dx.doi.org/10.1007/s10940-010-9093-7

Bogoro, S. E. (2008). Management of Religious Conflict from a practitioner's view point. First Annual National Conference of Society for Peace Studies and Practice (SPSP), $15^{\text {th }}-18^{\text {th }}$ June, Abuja, Nigeria.

Britton, W., Davies, K., \& Johnson, T. (1998). Modern methods of Valuation (8th Ed.). Londom: The Estate gazette.

Buck, A. J., \& Hakim, S. (1989). Does Crime Affect Property Value? Canadian Appraiser, 33, 23-37.

Buck, A. J., Deutsch, J., Hakim, S., Spiegel, U., \& Weinblatt, Z. (1991). A Von Thunen Model of Crime, Casinos and Property Values in New Jersey. Urban Studies, 28, 673-687. http://dx.doi.org/10.1080/00420987320080311

Chau, K. W., Ma, V. S. M., \& Ho, D. C. W. (2001). The pricing of Luckiness in the Apartment market. Journal of Real Estate Literature, 9(1), 31-40.

Choy, L. H. T., Mak, S. W. K., \& Ho, W. K. O. (2007). Modeling Hong Kong Real Estate Prices. Journal Hous and the Built Environ, 22, 359-368. http://dx.doi.org/10.1007/s10901-007-9089-2

Cozens, P., Hillier, D., \& Prescott, G. (2000). Crime and the Design of Residential Property- Exploring the Perceptions of Planning Professionals, Burglars and other Usera. Property Management, 19(4), 222-248. http://dx.doi.org/10.1108/EUM0000000005784

Court, A. T. (1939). Hedonic Price Indexes with Automobile example. The dynamics of Automobile Demand (pp. 99-117). New York general Motor Corp.

Dugan, L. (1999). The Effect of Criminal Victimization on a Household's moving Decision. Criminology, 37, 903-930. http://dx.doi.org/10.1111/j.1745-9125.1999.tb00509.x

Dung-Gwom, \& Rikko, L. (2009). Urban Violence and Emerging Land and Housing Markets in Jos, Nigeria. ISA Housing Conference, Glasgow, 1-4 September.

Ebru, C., \& Eban, A. (2011). Determinants of House Prices in Istanbul: A Quantile Regression Approach. Qual Quant, 45, 305-317. http://dx.doi.org/10.1007/s11135-009-9296-x

FAcE-PaM. (1998). A Memorandum Submitted to Administrative Commission of Inquiry in to Yelwa/Kagadama Civil Disturbances. FACE- paM publications, Bauchi, Nigeria. 
Field, E., Levinson, M., Pande, R., \& Visaria, S. (2010). Seggregation, Rent Control, and Riots: The Economics of Religious conflict in an Indian City. Venconpapers.repec.org/article/aeaaecrev/default98.htm (Accessed March 22, 2011).

Flippen, C. (2004). Unequal Return to Housing Investment? A Study of Real Housing Appreciation among Black. White and Hispanic Social Forces, 82, 1523-1552.

Frey, W. H. (1979). Central City White Flight: Racial and Nonracial Causes. American Sociological Review, 44, L425-448. http://dx.doi.org/10.2307/2094885

Gallimore, P., Fletcher, M., \& Carter, M. (1996). Modelling the Influence of Location on Value. Journal of Property Valuation and Investment, 14(1), 6-19. http://dx.doi.org/10.1108/14635789610107444

Gambo, Y. L. (2009). Impact of Violent Ethno-Religious Conflict on Residential Property Value Determinants I Northern Nigeria. M.Sc Thesis Submitted to Department of Estate Management University of Lagos.

Gambo, Y. L. (2011). Violent Ethno Religious conflict and Settlement Pattern in Northern Nigeria: The Dilemma of Urban Dynamics. National Conference, University of Lagos, Nigeria 3-4 November.

Gibson, S. (2004). The Costs of Urban Property Crime. The Economic Journal, 144, 441-463.

Innes, M., \& Jones, V. (2006). Neighbourhood Security and Urban Change: Risk, Resilience and Recovery, Report from Joseph Rown Tree Foundation.

Institute for Peace and Conflict Resolution, IPCR. (2003). Strategic Conflict Assessment: Consolidated and Zonal Reports, IPCR, Abuja.

Haurin, D. R., \& Brasington, D. (1996). School Quality and Real House Prices: Inter: And Intrametropolitan Effects. Journal of Housing Economics, 5, 351-368. http://dx.doi.org/10.1006/jhec.1996.0018

Horowitz, K. (1985). Ethnic Group in Conflict: Theories, Patterns, Policies. University of California Press.

Hsueh, L. M. (2000). The Relationship between House Price, Tenure Choice and Housing Behavior in Taiwan. International Real Estate Review, 3(I), 351-368.

Human Rights Watch. (2006). They Do Not Own This Place. Government Discrimination Against "Non-Indigenes" in Nigeria, 18(3), 1-64.

Kohlhase, J. E. (1991). The Impact of Toxic Wastes Sites on Housing Values. Journal of Urban Economics, 30(4), 1-26. http://dx.doi.org/10.1016/0094-1190(91)90042-6

Kukah, M. A. (2000). Democracy and Civil Society in Nigeria. Ibadan: Spectrum Books Ltd.

Lin, M. M., \& Brown, H. J. (1980). Micro-neigbourhood Externalities and Hedonic prices. Land Economics, 56(2), 125-141. http://dx.doi.org/10.2307/3145857

Lynch, A. K., \& Rasmussen, D. W. (2001). Measuring the Impact of Crime on House Prices. Applied Economics, 33, 1981-1989. http://dx.doi.org/10.1080/00036840110021735

Manning, C. (1986). Intercity Differencesin Home Price Appreciation. The Journal of Real Estate Research, 1, 45-65.

Mcmillen, D. P. (1990). Consistent Estimation of the Urban Land value functions. Journal of Urban Economics, 27(3), 285-293. http://dx.doi.org/10.1016/0094-1190(90)90002-5

Megbolugbe, I. F. (1989). A Heldonic Index Model: The Housing markets of Jos, Nigeria. Urban Studies, 26, 486-494. http://dx.doi.org/10.1080/00420988920080551

Mishra, S. K., \& Ngullie, M. L. (2008). Hedonic Demand for Rented House in kolima, Nagaland. Munich Personal Repec Archive.

Morenoff, J. D., \& Sampson, J. J. (1997). Violent Crime and the Spatial dynamics of Neigbourhood Transition: Chicago, 1970-1990. Soc. Forces, 76, 31-64.

Mohammed, S. A. (2004). The Impact of Conflict on the Economy: The case of Plateau State of Nigeria. Retrieved December 16, 2008, from www.odi.org.uk/events/nigeria_2004/

Mok, H. M. K. (1995). A Hedonic Approach to pricing of Residential properties in Hong Kong. Hong Kong Journal of Business Management, 8, 1-15.

Mok, H. M. R., Chan, P. P. K., \& Cho, Y. S. (1995). A Hedonic price model for private properties in Hong Kong. Journal of Real Estate finance and Economics, 10, 37-48. http://dx.doi.org/10.1007/BF01099610 
Nyabvedzi, F., \& Chirisa, I. (2012). Spatial Security and Quest of Solutions to Crime in Neighbourhoods in Urban Zimbabwe: Case in Marlborough East. Harare. Journal of Geography and Regional Planning, 5(3), 68-79.

Olayiwola, L. M., Adeleye, O. A., \& Oduwaye, A. O. (2005). Correlates of Land Value Determinants in Lagos metropolis, Nigeria. Journal of Human Ecology, 17(3), 183-189.

Otegbulu, A. C., \& Johnson, O. (2011). The Impact of Jacuzzi Bathtubs on House Prices. Journal of Sustainable Development, 4(3), 199-209. http://dx.doi.org/10.5539/jsd.v4n3p199

Otegbulu, A. C., Johnson, O., \& Odekoya, A. (2012). Determinants of Rent in Service Apartments. Real Estate Journal, 4(1).

Raji, B. R. (2003). The management of Ethno-Religious Violent Conflicts in Nigeria: A Case Study of Tafawa-Balewa and Bogoro Local Government Areas of Bauchi State. Unpublished Dissertation Submitted to the Institute of African Studies. University of Ibadan

Rapport, D. C. (1996). The Importance of space in Violent ethno Religious strife. Retrieved November 12, 2011, from www.worlat.org/identitis/iccen.81-66182

Rogers, R. (2005). Towards a Strong Urban Renaissance: An Independent Report by Members of the Urban Task Force Chaired by Lord Rogers of Riverside. Retrieved May 12, 2012, from www.urbantaskforce.org

Rosen, S. (1974). Hedonic Price and Implicit Markets: Product Differential in Pure Competition. Journal of Political Economy, 82(1), 35-55. http://dx.doi.org/10.1086/260169

So, H. M., Tse, R. Y. C., \& Ganesan, S. (1996). Estimating the Influence of Transport on House Prices: Evidence from Hong Kong. Journal of property valuation and Investment, 15(1), 40-47. http://dx.doi.org/10.1108/14635789710163793

Social Exclusion Unit. (2001). A New Commitment to Neighborhood Renewal. London: Cabinet office.

Thaler, R. (1978). A Note on the Value of Crime Co Troll: Evidence from the Property Market. Journal of Urban Economics, 5, 137-145. http://dx.doi.org/10.1016/0094-1190(78)90042-6

Tse, R. Y. C., \& Love, P. E. D. (2000). Measuring Residential Property Vaalues in Hong Kong. Property Management, 18, 366-374. http://dx.doi.org/10.1108/02637470010360669

U. S Agency for International Development, USAID. (2009). Land and Conflict: A Toolkit for Intervention.

Wilson, J., \& Kellings, G. (1982). Broken Windows. The Atlantic Monthly, March, pp. 29-38. 
Appendix 1. Samples of empirical studies in hedonic price modeling

\begin{tabular}{|c|c|c|c|c|}
\hline S/No & $\begin{array}{l}\text { Author(s), Year, } \\
\text { Country }\end{array}$ & $\begin{array}{l}\text { Classification } \\
\text { Variables }\end{array}$ & $\begin{array}{l}\text { Methodology/Model } \\
\text { Specification }\end{array}$ & Results/Findings \\
\hline 1 & $\begin{array}{l}\text { Magbelugbe I.F. } \\
\text { (1989)Jos Urban } \\
\text { Area, Nigeria } \\
1,310 \text { appraisal data } \\
\text { from property tax } \\
\text { assessment; made } \\
\text { up of } 1124 \\
\text { multifamily and } 186 \\
\text { single family units- } \\
\text { occupied mainly by } \\
\text { low-income and } \\
\text { moderate - income } \\
\text { households. }\end{array}$ & $\begin{array}{l}\text { Dependent variable: } \\
\text { Appraised annual } \\
\text { value(rating } \\
\text { assessments) } \\
\text { Independent variables: - } \\
\text { Building age, roof } \\
\text { cover, ceiling material, } \\
\text { nature of area and the } \\
\text { building floor (earth or } \\
\text { clay), building wall } \\
\text { (sand or concrete), roof } \\
\text { type; number of } \\
\text { kitchens, floors; } \\
\text { building floor area, } \\
\text { building gross area; if } \\
\text { building contain flats, } \\
\text { has fence, share } \\
\text { essential facilities; use } \\
\text { zoning, zoning density. }\end{array}$ & $\begin{array}{l}\text { Hedonic pricing model; Box - } \\
\text { Cox transformation; separate } \\
\text { analysis for single family, multi } \\
\text { - family and both combined; } \\
\text { market segmentation based a } \\
\text { prior on the type of design of } \\
\text { the houses. }\end{array}$ & $\begin{array}{l}\text { Box-Cox } \lambda \text { transformation } \\
\text { parameter is } 0.2 \text { for the } \\
\text { multi-family and }-0.1 \text { for the } \\
\text { single-family submarket. The } \\
\text { hedonic parameters of these } \\
\text { functional forms are } \\
\text { significantly different from } \\
\text { log-linear and linear } \\
\text { functional forms, and those } \\
\text { most commonly found in } \\
\text { literature. The author justifies } \\
\text { this claim by making } \\
\text { comparison with results of } \\
\text { similar studies in a number of } \\
\text { other developing countries. }\end{array}$ \\
\hline 2 & $\begin{array}{l}\text { Dunse, N.\& Jones, } \\
\text { C. (1998) Glassgow } \\
\text { city centre. } \\
477 \text { asking rent to } \\
\text { determine the } \\
\text { significant } \\
\text { determinants of } \\
\text { rental values for } \\
\text { office. }\end{array}$ & $\begin{array}{l}\text { Dependent variable: } \\
\text { Rent } \\
\text { Independent variables: } \\
\text { age, park area, distance } \\
\text { from st. Vincent street, } \\
\text { upper floor, ground } \\
\text { floor, basement, internal } \\
\text { parking, reception area, } \\
\text { security system, tea } \\
\text { preparation area. }\end{array}$ & $\begin{array}{l}\text { Employed linear functional for } \\
\text { of hedonic model, much } \\
\text { multicollinearity was found } \\
\text { because independent variables } \\
\text { are closely related. A stepwise } \\
\text { multiple regression was } \\
\text { employed to determine } \\
\text { variables with highest partial } \\
\text { correlation coefficient }\end{array}$ & $\begin{array}{l}\text { Location was found as } \\
\text { principal determinants of } \\
\text { rents. The results stress the } \\
\text { continued importance of the } \\
\text { CBD as an office centre, The } \\
\text { Chow Test shows an } \\
\text { F-statistics of } 0.86 \text { while table } \\
\text { critical value is } 1.57 \text { for } 5 \% \\
\text { significance }\end{array}$ \\
\hline 3 & $\begin{array}{l}\text { Afolayan A. S. } \\
\text { (2006). Lagos, } \\
\text { Nigeria } \\
\text { The study explains } \\
\text { the extent to which } \\
\text { the lagoon as an } \\
\text { environmental } \\
\text { externality affects } \\
\text { housing values in } \\
\text { Victoria Garden } \\
\text { City (VGC), Lagos, } \\
\text { Nigeria, using } 15 \\
\text { household units. }\end{array}$ & $\begin{array}{l}\text { Dependent variable: } \\
\text { Property value } \\
\text { Independent variables: } \\
\text { House type, plot size, } \\
\text { number of floors, age of } \\
\text { building, repairs, road } \\
\text { network, drainage } \\
\text { facility, security level, } \\
\text { noise control level, } \\
\text { lagoon view from house, } \\
\text { accessibility }\end{array}$ & $\begin{array}{l}\text { A multiple regression approach } \\
\text { was adopted. A sample size of } \\
\text { about } 150 \text { housing units about } \\
25 \% \text { of the sample frame using } \\
\text { stratified sampling technique } \\
\text { was used. }\end{array}$ & $\begin{array}{l}\text { The result exhibits } 93.2 \% \\
\text { explanatory power for } \\
\text { property values in VGC. Plot } \\
\text { size and number of floors are } \\
\text { revealed as more powerful } \\
\text { predictors of value therein } \\
\text { than the effect of lagoon and } \\
\text { its accompanying features. }\end{array}$ \\
\hline 4 & $\begin{array}{l}\text { Choy, L.H.T, Mak, } \\
\text { S.W.K. \& Ho, } \\
\text { W.K.O. (2007) } \\
\text { Hong Kong } \\
749 \text { samples from } \\
\text { Quarry Bay District } \\
\text { made up of several } \\
\text { small \& one mega - } \\
\text { scale housing estate } \\
\text { occupied mainly by } \\
\text { middle-income } \\
\text { earners. }\end{array}$ & $\begin{array}{l}\text { Dependent variable = } \\
\text { Inflation adjusted } \\
\text { transaction prices. } \\
\text { Independent variables = } \\
\text { total gross floor area, } \\
\text { age, floor level, garden } \\
\text { view, sea view, bad } \\
\text { view, transport } \\
\text { accessibility, luck } \\
\text { number }\end{array}$ & $\begin{array}{l}\text { Linear form; White's test used } \\
\text { to detect possible } \\
\text { heteroskedasticity; used Newey } \\
\text { - West Heteroskedasticity } \\
\text { consistent conveniences to } \\
\text { correct observed } \\
\text { heteroskedacity and } \\
\text { correlations among } \\
\text { observations in cross sectional } \\
\text { data. Prices adjusted using the } \\
\text { "Monthly Price Indices for } \\
\text { Selected Popular Private } \\
\text { Domestic Developments". }\end{array}$ & $\begin{array}{l}\text { Most variables are statistically } \\
\text { significant at conventional } \\
\text { levels: and exhibited } \\
\text { conventional signs. } \mathrm{R}^{2}=85 \% \\
\text { approx. Larger size, higher } \\
\text { floor level, and better view } \\
\text { commands a higher } \\
\text { transaction prices. Property } \\
\text { closer to the mass transit } \\
\text { railway station commands a } \\
\text { premium. Non- linear effect of } \\
\text { floor level exerts an impact on } \\
\text { prices. Feng Shui (luck } \\
\text { number) also has influence on } \\
\text { house prices. }\end{array}$ \\
\hline
\end{tabular}


Appendix 1. Samples of empirical studies in hedonic price modeling (continued)

\begin{tabular}{|c|c|c|c|c|}
\hline S/No & $\begin{array}{l}\text { Author(s), Year, } \\
\text { Country }\end{array}$ & Classification of Variables & $\begin{array}{l}\text { Methodology/Model } \\
\text { Specification }\end{array}$ & Results/Findings \\
\hline 5 & $\begin{array}{l}\text { Mok, H.M.K, } \\
\text { Chan,P.P.K \& Cho, } \\
\text { Y-S (1995). Hong } \\
\text { Kong } \\
1027 \text { actual apartment } \\
\text { sales price were used } \\
\text { within a 5-Minute } \\
\text { walking distance in the } \\
\text { captured zones of 13 } \\
\text { Mass transit Transit } \\
\text { Railway stations to } \\
\text { explore the effects of } \\
\text { Locational, Structural } \\
\text { and neighbourhood } \\
\text { attributes on private } \\
\text { condominium prices in } \\
\text { a space of one month } \\
\text { (august 1990) }\end{array}$ & $\begin{array}{l}\text { Dependant Variable: Selling } \\
\text { price } \\
\text { Independent Variables: distance } \\
\text { from CBD, storey, seaview, } \\
\text { gross floor area, age of the } \\
\text { building, school zone, big } \\
\text { estate, entertainment/sport } \\
\text { facilities }\end{array}$ & $\begin{array}{l}\text { Hedonic Pricing Model: } \\
\text { Box-Cox technique; } \\
\text { separate analysis for each } \\
\text { specification and for all } \\
\text { variables. }\end{array}$ & $\begin{array}{l}\text { Prices (dependent } \\
\text { variable)found to be } \\
\text { sensitive to changes to the } \\
\text { age of the building } \\
\text { (negative), the distance } \\
\text { from CBD(negative), and } \\
\text { the floor of the apartment } \\
\text { (positive). } \\
\text { Box-Cox transformation is } \\
0.71 \text { for the dependent } \\
\text { variable which is higher } \\
\text { than the } 0.2 \text { and } 0.4 \text { found } \\
\text { in US cities in earlier } \\
\text { studies (Linneman, 1980). }\end{array}$ \\
\hline 6 & $\begin{array}{l}\text { Mishra, S.K. \& } \\
\text { Ngullie M.C., Kohima, } \\
\text { capital city of } \\
\text { Nagaland, India, } 2008 . \\
\text { Sample survey of } 109 \\
\text { households living in } \\
\text { rented houses } \\
\text { randomly selected } \\
\text { from residents of } 19 \\
\text { wards(11 from each } \\
\text { ward) in Kohaima } \\
\text { capital city of } \\
\text { Nagaland, India In } \\
2008\end{array}$ & $\begin{array}{l}\text { Dependent variable: House rent } \\
\text { Independent variables: House } \\
\text { type, plot size, floor area, No of } \\
\text { rooms, no of occupants, nature } \\
\text { of ownership, distance from the } \\
\text { nearest building, receiving } \\
\text { enough sum share, parking } \\
\text { space, waste disposal, facilities, } \\
\text { drainage, public garden/ park } \\
\text { nearby, water supply, regularity } \\
\text { and source of water supply, } \\
\text { nature of toilet, power } \\
\text { connection, load-shedding or } \\
\text { power failure, noise pollution, } \\
\text { air pollution, water pollution, } \\
\text { nature of water pollution, } \\
\text { respondents feeling of } \\
\text { satisfaction with the house, } \\
\text { safety, income, family size and } \\
\text { rent. }\end{array}$ & $\begin{array}{l}\text { All variables (dependent } \\
\text { and independent) are } \\
\text { transformed into their } \\
\text { (natural) logarithmic } \\
\text { values. }\end{array}$ & $\begin{array}{l}\text { Study suggests that } \\
\text { consumers of rented house } \\
\text { consider floor area, water } \\
\text { supply and power supply } \\
\text { complimentary to each } \\
\text { other while other } \\
\text { characteristics of house as } \\
\text { substitutes of the floor } \\
\text { area. Rented house is an } \\
\text { inferior commodity and its } \\
\text { income elasticity for the } \\
\text { overall sample is negative, } \\
\text { though statistically } \\
\text { insignificant. }\end{array}$ \\
\hline 7 & $\begin{array}{l}\text { M.O. Bello and V.A. } \\
\text { Bello, 2008, Akure, } \\
\text { Nigeria. } \\
\text { Sample survey of } 190 \\
\text { households living in } \\
\text { rented houses in } \\
\text { randomly selected } \\
\text { from two communities } \\
\text { of Akure. }\end{array}$ & $\begin{array}{l}\text { Dependent variables: Annual } \\
\text { rent Independent variables: } \\
\text { Wall, ceiling, roof, window, } \\
\text { room size; availability of } \\
\text { kitchen, toilet, water, fence, } \\
\text { conditions of access, electricity } \\
\text { drainage, crime, number of } \\
\text { approved private schools and } \\
\text { number of public schools, } \\
\text { income of household heads, } \\
\text { number of dependents, number } \\
\text { of years spent on formal } \\
\text { education, gender, length of } \\
\text { stay in the developing and } \\
\text { distance away from offensive } \\
\text { refuse dump. }\end{array}$ & $\begin{array}{l}\text { Study used a two-stage } \\
\text { hedonic model. First } \\
\text { stage to model property } \\
\text { values as a function of } \\
\text { housing attributes, while } \\
\text { the second stage model } \\
\text { willingness to pay. }\end{array}$ & $\begin{array}{l}\text { The study identified } \\
\text { households income, } \\
\text { distance away from waste } \\
\text { dump site and regularity of } \\
\text { electricity supply as the } \\
\text { major significant factors } \\
\text { influencing household } \\
\text { willingness to pay for } \\
\text { better environmental } \\
\text { services. }\end{array}$ \\
\hline
\end{tabular}


Appendix 1. Samples of empirical studies in hedonic price modeling (continued)

\begin{tabular}{|c|c|c|c|c|}
\hline S/No & $\begin{array}{l}\text { Author(s), Year, } \\
\text { Country }\end{array}$ & $\begin{array}{l}\text { Classification of } \\
\text { Variables }\end{array}$ & $\begin{array}{l}\text { Methodology/Model } \\
\text { Specification }\end{array}$ & Results/Findings \\
\hline 8 & $\begin{array}{l}\text { Ajide K. B. and } \\
\text { Alabi, M. Lagos, } \\
\text { Nigeria. } 2010 . \\
\text { Sample of } 983 \\
\text { households through } \\
\text { survey using Lagos } \\
\text { statae Household } \\
\text { Survey as sample } \\
\text { frame. }\end{array}$ & $\begin{array}{l}\text { Dependent variable: } \\
\text { Monthly rent. } \\
\text { Independent variables: } \\
\text { Room size, age, floor } \\
\text { level, kitchen, wall } \\
\text { material, toilet } \\
\text { facilities, ceiling, } \\
\text { fencing, window, } \\
\text { water, drainage, crime } \\
\text { rate, pollution level, } \\
\text { accessibility to } \\
\text { employment, children } \\
\text { school, hospital, } \\
\text { market, recreational } \\
\text { centre, and public } \\
\text { transport. }\end{array}$ & $\begin{array}{l}\text { Hedonic price model using the } \\
\text { three functional forms - linear, } \\
\text { semi-log and double-log - for } \\
\text { purpose of comparison. The } \\
\text { study showed that semi-log is } \\
\text { the best of the three. }\end{array}$ & $\begin{array}{l}\text { Of the three functional forms, } \\
\text { semi-log gives the best fit with } \\
\mathrm{R}^{2}=0.67 \text {, while the linear and } \\
\text { double-log is } 0.56 \text { and } 0.63 \text {, } \\
\text { respectively. This confirms the } \\
\text { number of earlier stud,,,es that } \\
\text { a non-linear functional form } \\
\text { performs better than a linear } \\
\text { form. Furthermore, structural } \\
\text { attributes were found to be } \\
\text { more statistically more } \\
\text { significant than locational and } \\
\text { neighborhood attributes in } \\
\text { influencing house prices in } \\
\text { Lagos, Nigeria. }\end{array}$ \\
\hline 9 & $\begin{array}{l}\text { Babawale,G.K.\& } \\
\text { Adewunmi,Y. } \\
\text { (2011), } \\
\text { Lagos,Nigeria. } \\
450 \text { apartments to } \\
\text { investigate the } \\
\text { impact of } \\
\text { neighbourhood } \\
\text { churches on } \\
\text { residential property } \\
\text { values }\end{array}$ & $\begin{array}{l}\text { Dependent variable: } \\
\text { Rental value } \\
\text { Independent variables: } \\
\text { distance to religious } \\
\text { property, parking } \\
\text { space, number of } \\
\text { bedrooms, number of } \\
\text { baths/toilets, distance } \\
\text { to work, access road, } \\
\text { security, condition of } \\
\text { property }\end{array}$ & $\begin{array}{l}\text { Employed the log-log } \\
\text { functional form of hedonic } \\
\text { model. }\end{array}$ & $\begin{array}{l}\text { Linear, semi-log and double log } \\
\text { functions were tested. The } \\
\text { results show that } \\
\text { neighbourhood churches, } \\
\text { particularly the large ones } \\
\text { impact negatively on the nearby } \\
\text { residential properties such that } \\
\text { house price increase by about } \mathrm{N} \\
310 \text { for every additional one } \\
\text { meter distance away from a } \\
\text { church premises. }\end{array}$ \\
\hline 10 & $\begin{array}{l}\text { Otegbulu, .A.C., } \\
\text { Johnson, O. \& } \\
\text { Odekoya, A. (2012). } \\
\text { Lagos, Nigeria. } \\
54 \text { service apartment } \\
\text { to examine the } \\
\text { effects of physical } \\
\text { and Locational } \\
\text { attributes, service } \\
\text { provided and } \\
\text { occupancy } \\
\text { restrictions on } \\
\text { service apartment }\end{array}$ & $\begin{array}{l}\text { Dependent variable: } \\
\text { Annual rent } \\
\text { Independent variable: } \\
\text { No. of bedrooms, } \\
\text { internal floor, age of } \\
\text { the building, floor } \\
\text { level. Balcony, } \\
\text { modern kitchen, } \\
\text { quality of furnishing, } \\
\text { sea/lagoon view, maid, } \\
\text { services, utility paid, } \\
\text { lease terms, internet, } \\
\text { distance to place of } \\
\text { work }\end{array}$ & $\begin{array}{l}\text { Adopted semi-log functional } \\
\text { form of hedonic price model to } \\
\text { evaluate the attributes that } \\
\text { determine the rent of service } \\
\text { apartment. Durbin Watson } \\
\text { statistics of } 1.820 \text { indicates the } \\
\text { model is free from } \\
\text { auto-correlation. The model } \\
\text { passes the white's } \\
\text { heteroscendasticity test with } \\
\text { F-statistics of } 1.6311, \mathrm{P}= \\
0.2413\end{array}$ & $\begin{array}{l}\text { The results show that } \\
\text { miscellaneous amenities, } \\
\text { utilities, en-suit rooms, } 24 \text { hour } \\
\text { electricity, number of } \\
\text { bedrooms, modern kitchen, } \\
\text { balcony, full air conditioning, } \\
\text { quality of finishing, are the } \\
\text { most significant attributes } \\
\text { influencing the rent of service } \\
\text { apartment. }\end{array}$ \\
\hline
\end{tabular}

